\title{
COVID-19 - neuropathological point of view, pathobiology, and dilemmas after the first year of the pandemic struggle
}

\author{
Jaśmina Sieracka1 ${ }^{1}$ Przemysław Sieracki², Grzegorz Kozera ${ }^{3}$, Edyta Szurowska ${ }^{4}$, Jacek Gulczyński ${ }^{5,6}$, \\ Piotr Sobolewski ${ }^{7,8}$, Wojciech Kloc ${ }^{9,10}$, Ewa Iżycka-Świeszewska ${ }^{5,6}$ \\ ${ }^{1}$ Department of Neurology, Medical University of Gdansk, Poland, ${ }^{2}$ Psychiatric Department, SPS ZOZ Lebork, Poland, ${ }^{3}$ Medical \\ Simulation Centre, Medical University of Gdansk, Poland, ${ }^{4}$ Second Department of Radiology, Medical University of Gdansk, Poland, \\ ${ }^{5}$ Department of Pathology and Neuropathology, Medical University of Gdansk, Poland, ${ }^{6}$ Department of Pathomorphology, Copernicus \\ Hospitals, Gdansk, Poland, ${ }^{7}$ Department of Neurology and Stroke Unit, Holy Spirit Specialist Hospital in Sandomierz, Poland, \\ ${ }^{8}$ Collegium Medicum, Jan Kochanowski University, Kielce, Poland, ${ }^{9}$ Department of Psychology, Health Sociology and Public Health \\ School, University of Warmia and Mazury in Olsztyn, Poland, ${ }^{10}$ Department of Neurosurgery, Copernicus Hospitals, Gdansk, Poland
}

\begin{abstract}
This article constitutes a summary of the knowledge on the involvement of the nervous system in COVID-19, concerning its general pathobiology, clinical presentation and neuropathological features as well as the future directions of investigation. Variable definitions, selection bias, mainly retrospective analyses of hospitalized patients and different methodologies are implemented in the research of this new disease. Central nervous system (CNS) pathology presents most frequently features of non-specific neuroinflammation with microglial activation and lymphoid infiltrations, ischemic/hypoxic encephalopathy, acute cerebrovascular disease, and microthrombi. Some brain specimens remain unaffected or show only non-specific changes of the critical status. Interpretations of the neuropathological findings are not always balanced in a clinical context and discrepant in consequence. Designing of longitudinal neuropathological studies, more frequent autopsies, and building of COVID-19 brain banks, together with neuroimaging analyses is essential. Genetic predispositions or immunological factors corresponding to the disease profile as well as cerebrospinal fluid (CSF) or serum biomarkers of COVID-19, the impact of different virus variants and influence of the therapy need to be identified. The mechanisms causing neuroCOVID and cognitive impairment - whether they are infectious, toxic, vascular or metabolic - create other aspects under research. There are also many existential questions about post-COVID and delayed sequelae of the infection. The fight with pandemic is a challenge for the global society, with neuropathologists and neuroscientists as important allies in struggle for understanding and conquering COVID-19.
\end{abstract}

Key words: COVID-19, neuroCOVID, neuropathology, brain autopsy findings, SARS-CoV-2, pathobiology.

\section{Introduction}

The coronavirus disease COVID-19 is caused by a new virus - severe acute respiratory syndrome coronavirus 2 (SARS-CoV-2), originated in Wuhan,
China in late 2019, and soon spread across the world as a persistent pandemic with recurrent waves in most countries [14,94]. Official statistics show more than 130 million people infected with SARS-CoV-2 
and about 3 million fatalities; however, the real numbers are significantly higher. SARS-CoV-2 belongs to the positive-sensed RNA betacoronavirus family together with SARS-CoV-1 and MERS-CoV sharing some structural features as well as high transmissibility $[9,14,63]$.

This article constitutes a summary of the knowledge on the involvement of the nervous system in COVID-19, concerning its general pathobiology, clinical presentation and neuropathological features as well as the unanswered questions and future directions of investigation. Revealing the nature of neural involvement in COVID-19 is of great importance for comprehension of this new disease, with substantial implications in directing the clinical attitude. The mechanisms responsible for neurological aspects in COVID-19 on the clinical, histological, and molecular level are under intensive investigation because its acute and late consequences constitute an important topic for global health.

\section{Pathobiology of COVID-19}

The SARS-CoV-2 virus is primarily transmitted between people through respiratory droplets and contact routes. Its genome encodes proteins involved in replication and four structural proteins consisting of the spike glycoprotein, nucleocapsid, membrane, and envelope $[3,11,14,26]$. Viral nucleocapsid is surrounded by an envelope where glycoprotein spikes called S-proteins are located. The interaction between the S-proteins and the host receptors, mainly angiotensin converting enzyme 2 (ACE2) plays the most important role in SARS-CoV-2 cellular infectivity and invasion. The receptor is expressed on various levels in the respiratory tract (bronchial epithelial cells, pneumocytes), olfactory mucosa, endothelial cells, enterocytes, renal proximal tubular cells, and different components of the nervous system $[3,14,26]$. The data on topographic cerebral ACE2 expression are conflicting, the mRNA level of ACE2 does not accurately reflect protein expression $[9,19,26,85,89,91]$. This receptor has uneven distribution in the brainstem, motor cortex, glutaminergic neurons, and choroid plexus [19,27]. Virally induced downregulation of ACE-2 expression can enhance sympathetic activity in mice, through the angiotensin-renin-aldosterone axis control, and modifies the neuroimmunological response. It seems that infection can be prevented by blocking the central nervous system (CNS) located ACE-2 receptors with antibodies [89]. Other important receptors involved in SARS-CoV-2 invasion are basigin, neuropilin-1, and proteases priming $\mathrm{S}$ proteins, such as serine protease TMPRSS2, furin and cathepsin $[11,19]$. The exact mechanisms of SARS-CoV-2 neurovirulence or neurotoxicity remain unknown $[3,4,29,44,84]$. However, there is some evidence for direct neurotropism, the role of aberrant immune response, local circulatory dysfunction and hypoxia, inflammatory cytokines in the cerebrospinal fluid (CSF), and migration of infected monocytes/macrophages across the bloodbrain barrier (BBB). Potential tracts of SARS-CoV-2 spread to the CNS include: 1) transsynaptic neuronal - from peripheral to CNS through the olfactory nerves and probably also facial, glossopharyngeal, and vagus nerve; 2) haematogenous path due to interaction between the virus and ACE2 receptor in endothelial cells, with consecutive BBB penetration; 3) immunological route as the virus infects resident mucosal immune cells that disperse to other organs; 4) meningeal structures, choroid plexus, and circumventricular organs (CVO) entry via CSF and fenestrated blood vessels $[3,4,29,56,63]$; and 5) pathogen transmission via enterocytes, enteric plexus, sympathetic nerves and dendritic cells, as in herpes, influenza and enteroviral entities [19]. However, a capacity to enter the CNS and infect neurons directly does not seem to determine whether or when a strain causes neurovirulence. The most likely explanation for this is induced neuroinflammation in various forms $[3,9,56]$. Peripheral cytokine release following an infection may lead to important consequences in the CSF and brain, particularly due to indirect activation of microglia $[8,84]$. It is known from the H1N1 novel influenza A infection that microglial priming affecting the brain in several contexts might lead to long-lasting brain dysfunction and/or increased susceptibility to various inflammatory stimuli [8].

The immune response induced by SARS-CoV-2 has the first phase of adaptive local innate immune response in the naso-, pharyngeal and bronchial mucosa, with activation of NLRP3 inflammasome $[54,60]$. Replication of the virus is greatest just before or soon after symptom onset. Antigen-presenting cells induce a population of virus-specific $T$ and $B$ lymphocytes. When innate mechanisms are ineffective or exhausted, the hyper-inflammatory disease develops with pneumonia, ARDS and severe systemic symptoms $[29,32,49,56,63,100]$. A crucial 
role in this phase of the disease is played by a complex mechanism of "cytokine storm" $[4,21,38,49,52$, $56,63,67,91,100,101]$. SARS-CoV-2 is able to delay the induction of type I interferon (IFN) and trigger a huge release of proinflammatory factors, particularly interleukin (IL)-6, and also tumour necrosis factor $\alpha$ (TNF- $\alpha$ ), IL-2R, IL-8, IL-10, IL-15, IL-1 $\beta$, soluble TNF receptor, INF- $\gamma[25,76,85]$. Highly impaired IFN type I response is characterized by no IFN- $\beta$ and low IFN- $\alpha$ production and activity [36]. The additional immune dysregulation occurs through the hypothalamus-pituitary-adrenocortical axis activation of the autonomic nervous system and neurohumoral induced emergency myelopoiesis $[32,63,85,99]$. The cytokine storm leads to BBB damage, dysfunction of astrocytes, and activation of microglia. Altogether it can cause acute encephalopathy, hypoperfusion, hypoxia and coagulation disturbances [26,44], demyelination, aberrant neuronal signalling, cell damage, and death [2,3,29,48,62,85]. Inflammatory cytokines can be detected in the CSF weeks after SARS-CoV-2 infection, with IFN- $\beta$ and IL-8 specifically enriched in the CSF compared with plasma [84].

Song et al. [89] modelling SARS neuroinvasion, observed a hypermetabolic state unique to SARS-CoV-2-infected cells adapting the host neuron machinery for replication, and a large number of neural cells dying in human brain organoids. The locally hypoxic environment affected survival of nearby cells, and host metabolic reprogramming. In this study, the electron microscope revealed viral replication as particles budding from neuronal endoplasmic reticulum. The increasing viral titres in the brain of mice after intranasal administration, with viral distribution throughout forebrain were seen. The next finding was remodelling and disturbance of brain vasculature and vulnerability of metabolically active regions to ischemia and higher susceptibility to a further viral invasion [89].

Recently, de Virgiliis et al. [94] have showed a possibility of neuroinfectivity in COVID-19 within the lung parenchyma. The afferent and efferent innervation crosstalk with the immune system to modulate lung and respiratory tract function through sensory, autonomic fibres, and neuroepithelial cell bodies with different neurotransmitters. Nerve- and airway-associated macrophages constitute a new subset of resting macrophages taking part in viral response via neural control, creating a so-called neuroimmune unit $[44,94]$.
When considering SARS-CoV-2 it is necessary to mention other epidemic viruses. The most common extra-respiratory complications of the influenza $A$ and measles virus are also neurological [62]. Some authors notice resemblance even between HIV/AIDS and COVID-19. HIV as a lympho- and neurotropic virus enters the CNS during early infection. Chronic HIV infection relates to BBB alteration and a spectrum of neuropathological changes comprising, inter alia, vasculopathy, amyloid deposits, and HIV-dementia even in young patients [5,6,40,46]. Moreover, long-term HIV infection, with virus-positive CSF is associated with the risk of poorer neurocognitive performance [90]. There are data that SARS-CoV-2 infects lymphocytes, granulocytes, and monocytes and can be detected in CSF $[44,96]$. Lymphopenia accompanied by drastic reduction of $\mathrm{CD} 4+\mathrm{T}$ cell count points poor clinical outcome in COVID-19 patients, similarly to HIV infection evolution. In CSF in severe neuroCOVID, expansion of dedifferentiated monocytes, exhausted CD4+ T cells, and lower interferon response than in viral encephalitis have been described [40]. Furthermore, CD4+ lymphocytes control gut microbiota, so together with the infection of enteric mucosa, dysbiosis-immune hyper-response-inflammation axis can in addition trigger gut-brain axis alterations [76].

The specific spectrum of symptoms caused a focus of attention on the neural profile of COVID-19. The prevalence of subjective olfactory and gustatory dysfunction depends on the virus subtype, but in a big series of 2020 European patients was found in $73.7 \%$ and $46.8 \%$ respectively, being most common in milder cases [57]. The general data are not consistent if the targets of a viral neuroinvasion are sustentacular cells, olfactory epithelium or sensory neurons $[54,88]$. Experimental models prove that SARS has the potential of brain invasion after intranasal application in laboratory animals [68,89]. The virus undergoes replication with consecutive neural cell damage and death through autophagy, apoptosis, pyroptosis or other ways [54,60]. De Melo et al. [69] report that SARS-CoV-2 proliferation in the olfactory epithelium is associated with local inflammation, induces acute anosmia and ageusia in hamsters, both lasting as long as the virus remains in the olfactory epithelium and bulb. Similarly, olfactory mucosa sampling in COVID-19 patients reveals the presence of virus transcripts and of SARS-CoV-2-infected cells, together with protracted inflammation 
$[10,11,38,62,68]$. Meinhardt et al. [68] studied nasal mucosal-nervous niche and carried out regional mapping of the olfactory pathway in autopsy material of 33 COVID-19 patients. Polymerase chain reaction (PCR), immunohistochemistry (IHC) and electron microscopy (EM) demonstrated the presence of SARS-CoV-2 RNA and protein in nasopharynx and brain specimens. The virus followed neuroanatomical structures, consecutive areas and brainstem cardiovascular regulatory centres, with site-specific local CNS infection. They found upregulation of HLA-DR on microglia/macrophages with microglial nodule formation, a relatively low number of viral particles, and relation between the duration of the disease and the viral load and location [68]. Importantly, it should be mentioned that anosmia with diverse mechanisms is also observed in a significant proportion of cases of chronic rhinosinusitis, aging, neurodegenerative diseases, and in a so-called post-viral olfactory disorder $[16,58]$. Normally, the replacement of olfactory neurons is accomplished by the basal stem and progenitor cells in the basal germinal olfactory epithelium zone, which is an active neurogenic niche. In inflammatory conditions, cytokines may directly impair olfactory sensory neurons and the regenerative response of basal cells [88]. In aging and neurodegenerative diseases, hyposmia/anosmia often precedes the typical symptoms. Post-viral olfactory disorder has unclear aetiology, and approximately $1 / 3$ of patients do not recover completely. Biopsies reveal peripheral damage to the olfactory epithelium, with a failure in regeneration $[16,58]$.

\section{Clinical presentation of COVID-19}

The clinical image of COVID-19 patients ranges from an asymptomatic course, through common cold, sinusitis, acute respiratory illness with fever, bronchitis, to pneumonia and acute respiratory distress syndrome (ARDS) $[14,34,94]$. Importantly, the disease is not always confined to the respiratory profile, and acute extrapulmonary COVID-19 such as gastrointestinal, cardiac, neurologic, psychiatric, dermatological, and mixed forms constitute a significant proportion of cases $[3,36,87]$. The course of the disease depends on the patient's age and comorbidities, where risk factors for complications include older age, cardiovascular disease, chronic lung disease, diabetes, and obesity. The ongo- ing mutations of the virus influence its infectivity, virulence and clinical symptomatology $[11,54,94]$. For clinical management, COVID-19 is divided into asymptomatic, mild, moderate, severe, and critical. Patients with mild cases usually recover isolated at home, moderate disease should be monitored and sometimes hospitalized, while severe cases need hospitalization, sometimes ending in an intensive care unit $[26,40,75,86]$. Laboratory tests in COVID-19 patients usually show lowered lymphocyte and platelet counts and higher blood urea nitrogen or d-dimer levels [11,75]. COVID-19-associated alterations of the innate immune system can lead to secondary infections with serious consequences. The severe form of the disease is characterized by poor oxygen saturation, massive pneumonia, a hyper-inflammatory state, generalized hypoxia, and thrombotic coagulopathy with multifaceted complications, and possibility of a fatal outcome. One of specific COVID-19 courses is multisystem inflammatory syndrome (MIS-C), first described in children [8]. Treatment of COVID-19, depending on the stage, includes antiviral drugs (remdesivir, etc.), chloroquine, antibiotics, convalescent plasma, antibodies, steroids, mechanic ventilation, and symptomatic control $[16,26,75,82,95,101]$. The therapeutic approach is constantly evolving, based on the progress in knowledge of disease pathobiology, resulting in updating guidelines which improve patient care and survival.

\section{Neurological and psychiatric manifestations in COVID-19}

Diverse neurological manifestations in COVID-19 patients play an important role in different phases of the disease, as a separate form or parallel to the respiratory illness [61]. It was observed that a significant number of patients treated for SARS-CoV-1 and MERS exhibited acute conditions and chronic neuropsychiatric sequelae $[28,37]$. Different other coronaviruses have been previously identified and considered as co-factors in pathogenesis of a variety of chronic neurological diseases [4]. SARS-CoV-2 affects the central and peripheral nervous system causing frequent olfactory and gustatory disturbances, acute or chronic headaches, acute cerebrovascular disease in ischemic and haemorrhagic form, encephalopathies and seizures. Much more rarely there occur encephalitis, myelopathies, Guillain-Barré syndrome, 
neuropathies or neuritis $[21,50,85]$. Skeletal muscle injury with myalgia, hyperCKemia and a few rhabdomyolysis cases, caused by viral or autoimmune myositis, were reported [85]. Heavy neurological manifestations can cause intensive care unit admission, higher risk of mortality and long-term neural and mental disorders $[21,26,28,50,85]$. The respiratory failure in COVID-19 has a postulated neural component owing to the viral injury to the brainstem respiratory centres $[10,85]$. Prolonged neurological symptoms are accompanied by a wide range of inflammatory cytokines, mediators that may persist in CSF for months after convalescence of the systemic disease [84]. The prevalence of significant neurological symptoms in COVID-19 varies between individual studies, ranging from $4.1 \%$ to $57.4 \%$ [40] and some aspects are underreported due to poor representativity of studied cohorts $[14,21,49,52]$. The discrepancies also result from other methodological deficits and short observation times as SARS-CoV-2 is regarded primarily as a respiratory infection. Fotuhi et al. [28] proposed a neuroCOVID staging: stage I - olfactory and taste disturbances, stage II - general inflammatory and cytokine reaction, hypercoagulable state, hyperimmunity, and neuro central/peripheral symptoms, stage III - cytokine storm, brain neuroinvasion, and heavy neuro symptoms. In addition, COVID-19 has also important neuropsychiatric effects in both short and longer term. The neuropsychiatric spectrum disorders consist of the altered mental status comprising unspecified encephalopathy, psychosis, delirium, cognitive and memory dysfunction. Moreover, insomnia, fatigue, depression, anxiety, agitation, brain fog, impaired consciousness, confusion, and coma occur. In general, patients with SARS-CoV-2 show higher symptoms of depression, anxiety and post-traumatic stress disorder symptoms when compared with non-COVID controls (Fig. 1) [23,28,39,43,75].

Stroke is one of the most serious complications of a SARS-Cov-2 infection in acute and subacute phases. The heterogenic forms of stroke may occur as non-specific effects of inflammation, endothelial dysfunction, hypoxia and coagulation disorders, imposed on pre-existing cerebrovascular risk factors $[41,45,85]$. During the first wave of the pandemic the hospitals significantly reduced care delivery $[22,66]$. The probability of an ischemic stroke incidence is much higher in hospitalized patients with severe COVID-19 than in patients with influenza [70] and it is a strong prognostic marker of a poor outcome. A significant group among the COVID patients presented with large vessel occlusion [65]. The data on the use of intravenous thrombolysis (IVT) and endovascular thrombectomy (EVT) during the first wave indicated significant limitations of these therapies. The information on the safety and effectiveness of IVT and EVT during next waves of the pandemic are promising, but in terms of long-term outcome are not available $[12,13,24]$.

\section{Neuroradiology in COVID-19}

In the majority of COVID-19 patients with anosmia, magnetic resonance imaging (MRI) shows bulb hyperintensity in a fluid-attenuated inversion recovery (FLAIR) sequence [51,78], whereas in other patient groups with the same symptoms, the olfactory nerve was normal [33]. Moreover, multiple focal hyperintense inflammatory lesions in FLAIR and T2 weighted images can be visible in the brain and spinal cord, with contrast-enhancement in some patients. These lesions should be differentiated between acute disseminated encephalomyelitis (ADEM) and multiple sclerosis (MS), especially in young people [72]. Meningoencephalitis is another possible CNS manifestation of a SARS-CoV-2 infection and requires contrast MRI study. ADEM can be diagnosed using MRI with a FLAIR sequence [72]. Diagnosis of Guillain-Barré syndrome may be established by contrast enhancement of nerve roots of the cauda equina and conus medullaris in MRI scans [103]. Radiological studies describe also small infarcts, microbleeds, posterior reversible encephalopathy syndrome [30,64], and CNS demyelination [79]. Multifocal necrotizing leukoencephalopathy as a result of COVID-19-related endothelial injury or thrombotic microangiopathy has been recently described [1]. The patients with persistent neurological symptoms manifesting as a chronic

$\begin{array}{ll}\text { NEUROLOGICAL - central and periph- } & \\ \text { eral nervous system involvement } & \\ \text { - hyposmia, dysgeusia } & \text { PSYCHIATRIC manifestation } \\ \text { - headache } & \text { - insomnia } \\ \text { - acute cerebrovascular disease } & \text { - fatigue } \\ \text { - encephalopathy } & \text { - depression } \\ \text { - seizure } & \text { - anxiety } \\ \text { - encephalitis } & \text { - agitation } \\ \text { - myelopathy } & \text { - cognitive impairment } \\ \text { - myopathy } & \text { - impaired consciousness, } \\ \text { - Guillain-Barré syndrome } & \text { confusion, coma, delirium } \\ \text { - other neuropathies and neuritis } & \end{array}$

Fig. 1. Summary of neurological and psychiatric COVID-19 manifestations. 
fatigue syndrome, did not show specific neuroimaging [35]. Ischemic stroke rates range from $1.6 \%$ in a Dutch case series of intensive care unit patients to $5 \%$ in two case series from Wuhan, China $[55,102]$. At present, COVID-19 patients currently undergo the same standards and protocols as non-COVID patients in order to make a timely decision about treatment in the acute stroke. Computed tomography (CT) is the gold standard in stroke diagnostics. In order to establish therapeutic strategy, CT-angiography, ASPECT score (Alberta stroke program early CT score) evaluation and/or other examinations such CT-perfusion or MRI are indicated (Fig. 2). The patients who present a hypercoagulable state may also develop venous thrombosis, which should be diagnosed with contrast-enhanced CT supplemented by CT-venography and CT-angiography because of possible multiple blood vessel simultaneous occlusion [73]. Haemorrhagic strokes can also occur in COVID-19 patients, even with normal platelet levels and without cardiovascular risk factors [18]. Some microhaemorrhages are caused by the endothelium damage by the virus, but a big haemorrhage can also be caused by acute hypertension or medium-size vessel endothelitis [93]. Vasculitis can be diagnosed by a contrast-enhanced-MRI high-resolution study, in the form of vessel wall thickening and a concentric enhancement pattern of the vessel wall. Microbleeds should be visualized in susceptibility weighted imaging (SWI) or T2* (gradient-echo imaging), sometimes in atypical locations, with a predominance in the corpus callosum. In the subacute and chronic phase, MRI with T1 weighted imaging with fat saturation and SWI is the method of choice. Longitudinal studies are needed in post-COVID population to assess microstructural and functional brain damage using diffusion tractography imaging and functional MRI because neuronal disorganization due to viral infection is possible. The amyloid positron emission tomography (PET) can also give a look inside such monitoring [35].

\section{COVID-19 neuropathology}

Autopsy studies provide a wealth of information regarding proportional, and cause-specific mortality, including death rates associated with leading public health priorities. Collection of specimens from cadavers can be useful in deciphering the causative pathogens and pathomechanisms, even after many years, which happened for example in the case of the Spanish flu and some other infectious diseases $[53,59,92]$. During the last West African Ebola epidemic, oral swabs were taken from cadavers to ensure that Ebola deaths did not go undetected. This practice led to the recognition of undocumented chains of transmission and permitted targeting of control measures and outbreak control [17]. Post-mortem testing for tissue viral load and drug metabolites can also provide some insight into treat-

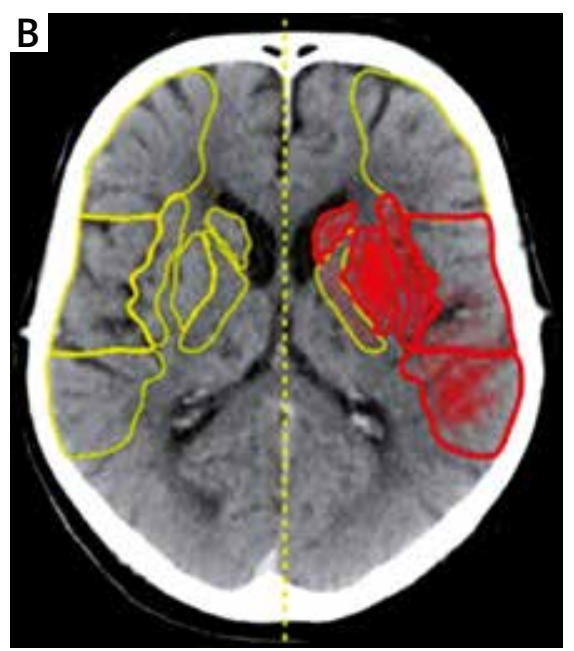

Fig. 2. A) A 66-year-old male patient hospitalized for severe COVID-19 with a clinical manifestation of stroke for 3 hours. This patient was transferred from another hospital to our centre. Non-contrast CT scans show the features of a large infarct in the left cerebral hemisphere, including the loss of insular ribbon, obscuration of lentiform nucleus, loss of grey-white matter differentiation. B) e-ASPECT highlights the acute ischemia within ASPECTS regions (ASPECT score -5 ). Authors' own material. 

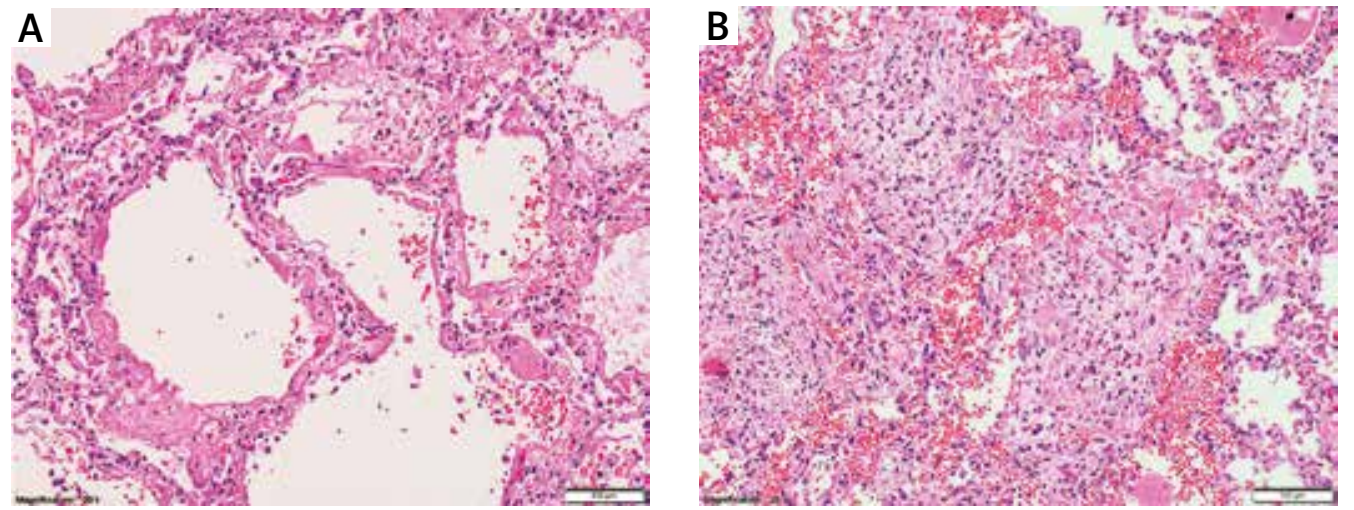

Fig. 3. Histopathology of pulmonary changes in COVID 70-year-old patient, showing: A) acute interstitial pneumonia and hyaline membranes, B) organizing bacterial pneumonia superimposing viral interstitial process, visible haemorrhages and thrombi (HE, own material).

ment uptake and effect. Even minimally invasive autopsies with targeted tissue sampling can provide reliable data on a certain disease [17]. At the beginning of the SARS-CoV-2 pandemic, the autopsies have been limited due to a lack of knowledge about its infectivity and limited personal protective equipment availability [17]. General post-mortem findings in COVID-19 most frequently show acute interstitial pneumonia, diffuse alveolar damage, ARDS features, bacterial pneumonia (Fig. 3), multi-organ thrombosis, myocarditis, spleen atrophy, shock kidneys, hemophagocytosis, and pancreatitis $[3,8,9,38]$. Many more other findings can be associated with this illness, but multicentre autopsy studies are necessary.

The reported post-mortem systematic neuropathological studies in COVID-19 patients are limited, since only circa 200 brain autopsies have been published per 2.5 million deaths. 29 available publications concerned post-mortem nervous tissue analysis $[2,3,10,11,20,25,31,32,38,48,49,52,56,67,68,71,74$, $80,81,9,82,83,86,87,97,99-101]$. Table I summarizes neuropathological studies in the literature. These reports usually regard small groups and case studies with different inclusion criteria, and diverse, often incomplete data. The patients varied in severity of the COVID-19 disease, neurological symptoms, age or comorbidities, often having a terminal mechanical ventilation. Thus, the pathological CNS changes represent a combination of direct effects of the virus and indirect effects of generalized or localized inflammatory response, thrombosis, multi-organ failure and individual sequelae $[3,32,54,87]$. The methods used to detect SARS-CoV-2 in tissues include immunohistochemistry with mono- or poly- clonal antibodies for spike proteins or nucleocapsid. The obtained results depend on the type of antibody applied, individual standardization of the protocol, and tissue pretreatment. The other methods of virus detection are in situ hybridization, qRT-PCR, and electron microscopy. Some published studies prompted a discussion in the literature due to an ambiguous picture or inadequate criteria used for morphologic diagnosis $[80,97]$.

Gross examination of COVID brain specimens usually shows oedema and congestion, with rarely different extent or focal vascular injury in the haemorrhagic or ischemic form. Some cases present predominant changes of the "respiratory brain" type. Microscopic findings range from no changes to multifactorial coexisting acute lesions $[61,67,87,99]$. In some cases, acute changes occur with pre-existing neuropathological diseases [61,71]. Common neuropathological observation is a mild perivascular, parenchymal as well as leptomeningeal reaction of T lymphocytes $[61,67]$. Moreover, a moderate to intense microglial reaction with activated forms, rods, and nodule formation is described, particularly in the brainstem [20] (Fig. 4). The analysis of the olfactory system revealed inflammation with a lymphocytic reaction, myelin and hypoxic injury $[10,11,61,68]$. The features of full-blown viral encephalitis were only incidentally described. The next common abnormality described was mild to moderate hypoxic injury, while infarcts were less frequent in the available neuropathological autopsy material. In some cases demyelination was detected, most probably secondary to vascular or axonal damage. Microbleeds and evident intravascular thrombosis were not 
Table I. Comparison of main neuropathological findings in COVID-19

\begin{tabular}{|c|c|c|c|}
\hline Authors & $\begin{array}{l}\text { Number } \\
\text { of patients }\end{array}$ & Main findings & $\begin{array}{l}\text { SARS-CoV-2 RNA in central } \\
\text { nervous system }\end{array}$ \\
\hline $\begin{array}{l}\text { Al-Dalahmah } \\
\text { et al. [2] }\end{array}$ & 1 & $\begin{array}{l}\text { Neuronophagia and microglial nodules with } \\
\text { perivascular lymphocytic infiltrates }\end{array}$ & $\begin{array}{l}\text { qRT-PCR positive in nasal } \\
\text { epithelium, olfactory bulb, } \\
\text { cerebellar clot, cerebellum }\end{array}$ \\
\hline Bryce et al. [9] & 23 & $\begin{array}{c}\text { Large and small infarcts, multiple small subcortical } \\
\text { infarcts, ischemic necrosis, microbleeds, focal } \\
\text { parenchymal infiltrate }\end{array}$ & Not reported \\
\hline $\begin{array}{l}\text { Bulfamante et al. } \\
{[10]}\end{array}$ & 1 & $\begin{array}{c}\text { Extensive damage of neurons, glia, nerve axons } \\
\text { and myelin sheath, more severe in olfactory bulb } \\
\text { and brainstem }\end{array}$ & $\begin{array}{c}\text { Particles referable to virions } \\
\text { of SARS-CoV-2 }\end{array}$ \\
\hline $\begin{array}{l}\text { Cantuti-Castelvetri } \\
\text { et al. [11] }\end{array}$ & 6 & Pathobiology of anosmia & Not reported \\
\hline $\begin{array}{l}\text { Deigendesch et al. } \\
{[20]}\end{array}$ & 7 & Microglia activation, particularly in brainstem & $\begin{array}{l}\text { qRT-PCR positive in olfactory } \\
\text { bulb }(n=4) \text {, optic nerve }(n=2) \\
\text { not detected in brainstem and } \\
\text { cerebellum }\end{array}$ \\
\hline Delamarre et al. [21] & 1 & Acute necrotizing encephalopathy & SARS-CoV-2 not detected \\
\hline Freij et al. [31] & 1 & Meningoencephalitis with tuberculosis co-infection & CSF qRT-PCR negative \\
\hline $\begin{array}{l}\text { Hanley, Al-Sarraj } \\
\text { et al. [38] }\end{array}$ & 10 & $\begin{array}{l}\text { Moderate to intense activation of microglia, few } \\
\text { perivascular T lymphocytes, ischemia, haemorrhagic } \\
\text { transformation, mucormycosis }\end{array}$ & qRT-PCR positive \\
\hline $\begin{array}{l}\text { Jaunmuktane et al. } \\
{[48]}\end{array}$ & 2 & Infarcts, microbleeds, medulla inflammation & Not reported \\
\hline Jensen et al. [49] & 2 & $\begin{array}{l}\text { Cerebral microangiopathy, multifocal infarcts, } \\
\text { brainstem encephalitis }\end{array}$ & SARS-CoV-2 not detected \\
\hline Kantonen et al. [52] & 4 & $\begin{array}{c}\text { Microhaemorrhages, enlarged perivascular spaces, } \\
\text { hypoxia-associated features, minor intravascular } \\
\text { deposits of fibrinoid in cerebral and subarachnoid } \\
\text { vessels, axonal spheroids }\end{array}$ & $\begin{array}{l}\text { qRT-PCR negative in brain and } \\
\text { olfactory mucosa }\end{array}$ \\
\hline Matschke et al. [67] & 110 & $\begin{array}{l}\text { Ischemic infarcts, astrogliosis, activation of microglia } \\
\text { in the brainstem and cerebellum, HLA-DR positive } \\
\text { stain in subpial and subependymal location, } \\
\text { cytotoxic infiltration of T lymphocytes in meninges }\end{array}$ & $\begin{array}{l}\text { qRT-PCR positive in the frontal lobe } \\
\text { and/or medulla }\end{array}$ \\
\hline Meinhardt et al. [68] & 32 & Cerebral infarcts & $\begin{array}{l}\text { RT-qPCR positive in olfactory } \\
\text { mucosa }\end{array}$ \\
\hline $\begin{array}{l}\text { Paniz-Mondolfi } \\
\text { et al. [74] }\end{array}$ & & $\begin{array}{l}\text { SARS-CoV-2 particles in endothelial cells in frontal } \\
\text { lobes }\end{array}$ & qRT-PCR positive \\
\hline Puelles et al. [80] & 27 & Viral copies in the brain & $\begin{array}{l}\text { qRT-PCR positive in the frontal lobe } \\
\text { and/or medulla }\end{array}$ \\
\hline Reichard et al. [82] & 1 & $\begin{array}{c}\text { Mild oedema, white matter haemorrhages, infarcts, } \\
\text { hypoxic-ischemic injury }\end{array}$ & Not reported \\
\hline $\begin{array}{l}\text { Remmelink et al. } \\
\text { [83] }\end{array}$ & 17 & $\begin{array}{c}\text { Cerebral focal necrosis, haemorrhage, oedema, } \\
\text { cerebral spongiosis }\end{array}$ & $\begin{array}{l}\text { qRT-PCR positive in the frontal lobe } \\
\text { and/or medulla }\end{array}$ \\
\hline Schaller et al. [86] & 10 & Brain unaffected & Not reported \\
\hline Solomon et al. [87] & 18 & Hypoxic injury of the cerebrum and cerebellum & qRT-PCR positive \\
\hline Weyhern et al. [97] & 6 & $\begin{array}{c}\text { Encephalitis and/or lymphocytic meningitis, } \\
\text { microbleeds, neuronal loss, axon degeneration } \\
\text { (mainly brainstem) }\end{array}$ & Not reported \\
\hline Xu et al. [99] & 1 & Cerebral oedema due to hypoxia & SARS-CoV-2 negative \\
\hline Younger et al. [101] & 50 & $\begin{array}{c}\text { Hypoxic-ischemic injury, interstitial brainstem } \\
\text { inflammation with neuronal loss, leptomeningeal } \\
\text { inflammation, microbleeds, perivascular } \\
\text { parenchymal T-cells }\end{array}$ & Not reported \\
\hline
\end{tabular}



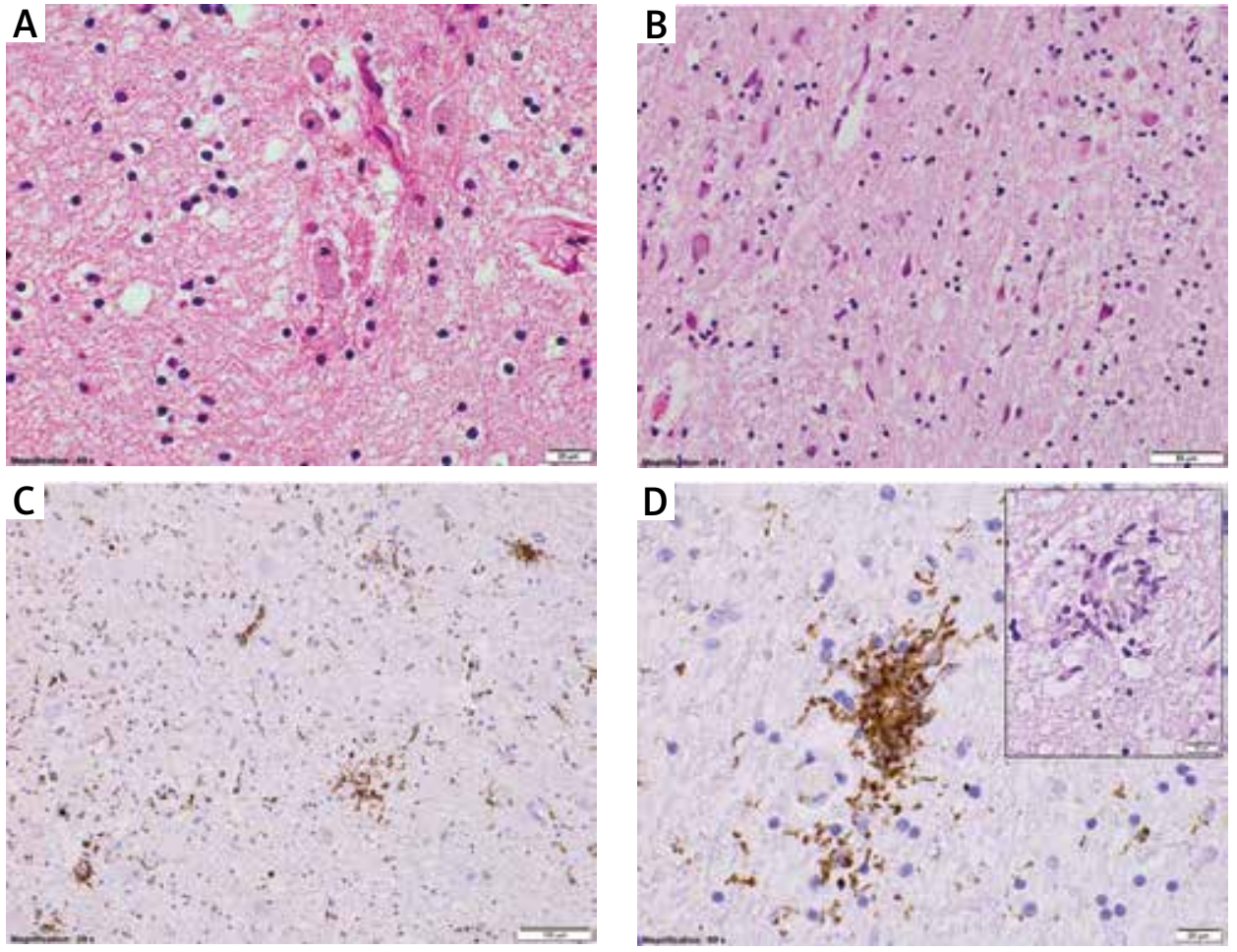

Fig. 4. Histopathology of cerebral changes in a 59-year-old patient, showing: A) grouping of macrophages, hemosiderin deposits around cerebral temporal lobe microvessel (HE), B) slight gliosis, selected neuronal shrinkage, tissue swelling $(\mathrm{HE}), \mathrm{C}, \mathrm{D})$ with insert $(\mathrm{HE})$ - brain stem section with microglial reaction showing activated forms and microglial nodules (CD68). Authors' own material.

a very common finding $[3,48,49]$. The short review of available neuropathological studies is presented below. In a study by Hanley et al. (8 autopsies) the main feature was moderate to intense activation of microglial cells, with a few perivascular $T$ lymphocytes [38]. Recent ischaemia of different extent was observed by them and Reichard et al. in the cortex and white matter as well as axonal damage proved by $\beta$ amyloid precursor protein (B-APP) accumulation [82]. In these studies, one case of haemorrhagic transformation of a recent cerebral infarction in the territory of the middle cerebral artery was detected. Al-Sarraj et al. [3] showed perivascular T lymphocyte infiltration in the frontal lobe and activated microglial cells in the unselected white matter $[3,38]$. Large and small subcortical infarcts, ischemic necrosis and small microbleeds were reported in several studies, by Bryce et al., Jaunmuktane et al., Reichard et al. or Remmelink et al. $[9,48,82,83]$. Bryce et al. in the examined 23 brains, found focal parenchymal T cell infiltrates in 2 cases [9]. Jaunmuktane et al. detected lymphocytic inflammation in the medulla in one case. SARS-CoV-2 presence was not proved in the above series [48]. The case report by Reichard et al. showed haemorrhages up to $1 \mathrm{~cm}$ disseminated through the white matter and few organizing microinfarcts. Myelin lesions/loss and oligodendrocyte apoptosis, together with generalized reactive gliosis in the white matter, was also seen [29,82]. Remmelink et al. [83] studied 17 cases, revealing brain oedema, cerebral haemorrhage or ischemic necrosis. Interestingly, they also noted no viral brain presence, although SARS-CoV-2 was found with real time (RT)-PCR in different organs. The important cofactors influencing the neuropathological picture are the effects of pharmacotherapy, ventilation, and lesions connected to the critical illness. Younger et al. analysed autopsies of 50 COVID-19 patients [101], but the study was limited due to missing clinical data regarding age and often even cause of death. SARS-CoV-2 reactivity in brain sections was negative. In this series, 25 patients had hypoxic ischemic changes and neuronal loss, there were 6 patients with brainstem inflammation, and seven with lep- 
tomeningeal inflammatory reaction [101]. Kantonen et al. [52] reported two autopsies including one of the patients with severe neurological symptoms. They found abundant small haemorrhages, hypoxia associated features, minor intravascular deposits of fibrinoid material in blood vessels, and dispersed axonal spheroids. Some vessels contained subendothelial haemorrhage and mild inflammation [52]. Von Weyhern et al. in a series of six patients described features of encephalitis and/or lymphocytic meningitis and petechial bleedings, additionally wide neuronal cell loss and axonal degeneration, especially in the brainstem [97]. Morphological changes in hypoxia-susceptible regions were consistent with those commonly revealed in other brains. This report provoked a discussion in "Lancet" in January 2021, where three groups of authors underlined that encephalitis is a rare entity in COVID, and all lesions need careful patho-clinical and neuropathological interpretation to avoid misinterpretation [97]. A study by Deigendesch et al. showed pronounced microglial activation mainly in the brainstem, but similar to the group of patients deceased from other, non-COVID septic conditions [20]. Jensen et al. presented one case with multi-territorial cerebral vascular disease, mainly in the form of watershed zone infarcts and cerebral microangiopathy, and the second case with brainstem encephalitis [49]. Bulfamante et al. in his case study depicted extensive damage of neurons, glia, axons and myelin, the most severe in the olfactory nerve, becoming milder with the growing distance from the gyrus rectus and brainstem. An abundance of SARS-CoV-2 virions was found [10]. Al-Dalahmah et al. reported a case of a diabetic man with a haemorrhagic focus in the cerebellar hemisphere [2]. Neuronophagia and microglial nodules in the inferior olives, and in the dentate nuclei, with mild perivascular lymphocytes, were present. RT-PCR was positive for SARS-CoV-2 in the nasal epithelium, olfactory bulb and cerebellum, but spike protein was not detected with immunohistochemistry [2].

Matschke et al. published a systematic neuropathological study of a series of 43 patients positive for SARS-CoV-2 in qRT-PCR, hospitalized in the spring 2020 [67]. The most common finding was neuroinflammation of the brainstem, astrogliosis, HLA-DR-reactivity and activation of the microglia with occasional microglial nodules in the medulla oblongata, perivascular and parenchymal infiltration with CD8-positive T cells. In only two cases neuronophagy was observed, in six other - ischemic infarctions, but no evidence of cerebral bleeding or small vessel thrombosis was found. 37 brains showed astrogliosis in all assessed regions since gliosis with different intensity and location was seen in all cases. Brainstem and cerebellum revealed diffuse activation of microglia. Additionally, positive staining for HLADR was found in subpial and subependymal regions. Proteins promoting viral entry: ACE2, TMPRSS2, TPCN2, TMPRSS4, NRP1 and CTSL were identified within the brain tissue. Frontal cortex and brainstem revealed a small amount of cytotoxic $T$ lymphocytes. In the brainstem, lymphocytes had mainly perivascular location, and 34 brains presented with low cytotoxic lymphocyte $T$ infiltration in the meninges. In the olfactory bulb, a high level of astrogliosis and microglial reaction was found [67]. Delamarre et al. [21] reported a case of a SARS-CoV-2-associated acute necrotizing encephalopathy, probably due to specific antibodies. This patient's IgG administered on rat and monkey samples presented unusual binding of immunoglobulin $\mathrm{G}$ ( $\mathrm{lgG}$ ) on specific areas in the nerve tracts [21]. Solomon et al. carried out a detailed clinical-neuropathological correlation of 18 patients hospitalized in April 2020, finding only hypoxic injury in the cerebrum and cerebellum in all cases. 11 patients received mechanical ventilation, all the patients had a confusional state and no MRI was available in this group. No thrombi, encephalitis or vasculitis were found, and no viral presence in immunohistochemistry. In qRT-PCR SARS-CoV-2 analysis, viral material was detected at low levels in 6 brain sections obtained from 5 patients, with inconsistent relation to the interval between the onset of symptoms and death $[29,87]$. Schaller et al. in 10 patients with ARDS obtained positive RT-PCR from respiratory tract specimens in all cases but negative in CSF, and the brains were reported as unaffected [86].

Cantuti-Castelvetri et al., detected SARS-CoV-2 in the olfactory epithelium in most of the analysed COVID-19 patients, using antibodies against S-protein. Infected olfactory epithelial cells presented a high expression of neuropilin 1, which was also observed in Olig2 positive olfactory neuronal progenitors [11]. Meinhardt et al. examined brains from 33 individuals with COVID-19 (March-August 2020), where they proved SARS-CoV-2 neurotropism and revealed cerebral microthrombosis with viral reac- 
tivity in endothelial cells. Olfactory mucosa samples were positive for RT-PCR. In 4 out of 13 samples, RNA assessment showed active virus replication. Viral load was extended in the olfactory bulb, trigeminal ganglion and medulla oblongata [68]. This study also supports the myeloid-derived inflammatory response in CSF and brain, upregulation of HLA-DR on microglia and neuroinflammation [68]. A study by Puelles et al. focused directly on multiorgan tropism of SARS-CoV-2 [80], showing the highest number of SARS-CoV-2 copies in the respiratory tract, then kidneys, liver, heart, brain and blood. Paniz-Mondolfi et al. reported one case where they found SARS-CoV-2 particles in neural and capillary endothelial cells in frontal lobe tissue [74]. Tested frozen tissues in RT-PCR assays targeting different regions of the viral genome were all positive for viral presence in brain tissue $[32,74]$. Freij et al. reported a case of fatal meningoencephalitis due to coinfection with tuberculosis in a child, showing negative tests for SARS-CoV-2 in CSF, but positive in the cerebellar sample [31]. Ramani et al., studying three patients, detected anti-Spike immunopositivity in cortical neurons and endothelial cells [81], and antibodies in CSF in a heavy course of COVID-19. They concluded that SARS-CoV-2 is neurotropic but does not invoke immune response similar to typical neurotropic viruses.

The above review shows that the knowledge about COVID-19 and neuroCOVID is limited. Collections of COVID-19 brain tissue with elaboration of international guidelines and establishment of research priorities are needed for the recognition of the real unbiased neuropathological spectrum of SARS-CoV-2 infection [97].

\section{Post-COVID-19 syndrome}

Some of the COVID-19 patients suffer from variable symptoms for many months from their initial infection, which is called long COVID or post-COVID syndrome $[26,32,56]$. This is the next challenge in the current pandemic. This condition can present as persistent fatigue, myalgia, abnormal thermoregulation, dysautonomia, intestinal disturbances, and often neurological as well as psychiatric dysfunction $[3,14,26,32,56,67,88]$. Some patients with mild COVID-19 develop prolonged cognitive alterations, headaches, sustained anosmia/dysgeusia or sensory hallucinations, brain fog, different forms of aphasia, and memory disturbances.
Many mechanisms are proposed: ongoing neuroinflammatory destruction, autoimmunity, viral latency, and accelerated neurodegeneration [3,14,26,38,49,56,87]. Persistent autoreactive $T$ cells and antibodies can migrate to the brain and cause a smouldering inflammatory process. Kreye et al. detected BBB dysfunction, neuronal damage and high levels of autoantibodies in CSF that target endothelial, glial and neuronal epitopes [56]. They also detected a fraction of high-affinity SARS-CoV-2-neutralizing antibodies that cause cross-reactivity with some antigens found in the CNS [56]. Remsik et al. [84] reported CSF presence of leptomeningeal inflammatory cytokines in the absence of the virus. The majority of these mediators driven by type II interferon are known to induce neuronal injury in other diseases. The levels of cytokines and metalloproteinase 10 correlated with the degree of neurologic dysfunction in this series [84]. The autoimmune reaction can be induced by the virus by autoreactive $T$ cells or cross-reactive virus neutralizing antibodies, both after the acute phase of infection or after viral clearance $[26,49,56]$. The autoimmunity can potentially affect the brain later, like post-herpetic autoimmune encephalitis with anti-NMDA antibodies, demanding careful differential diagnosis $[56,98]$. Another pathogenetic concept for post-COVID symptoms is the autonomic syndrome due to infection of postganglionic neurons and/or autoimmunity later on [99]. COVID-related dysautonomia can comprise circulatory component with chronic fatigue, postural tachycardia syndrome, palpitations, exercise intolerance, as well as $\mathrm{Gl}$ component in the form of chronic abdominal pain, gastroparesis and nausea $[91,99]$.

Finally, there is also a possibility of prolonged SARS-CoV-2 presence in the nervous tissue reservoir, but such studies are lacking. Early reinfections observed in some convalescents occur even after two months, suggesting reactivation of the virus from, for example, pulmonary tissue or nervous system. It is important to follow-up patients after COVID-19 acute illness, who have experienced or exhibit persistent/ fluctuating neurologic symptoms. It is suspected that these patients may have a higher risk of developing chronic neurodegenerative disease or other cognitive disorders $[59,76,91]$. The relations between viral infections and inflammatory/neurodegenerative disorders have been known for a long time, like in Western equine encephalitis, measles or influenza A H1N1 $[53,77,91]$. Common non-neurotrophic strains of influenza can cause injury to the hippocampus, interfering with normal behaviour after the acute infection [43]. 
Viral infections, such as HSV or flu may be associated with acceleration of tissue and molecular processes in Alzheimer's disease (AD) [62]. Post COVID- 19 shares also some similarities with the chronic phase of encephalitis lethargica - a disease of unestablished origin. This epidemic affected more than million individuals from 1916 till mid-twenties, coexisting for two years with Spanish flu (1918-1920). The 1918 influenza pandemic had a changing profile of morbidity and mortality, with mutating viral genotype [42,92]. In postencephalitic parkinsonism - late sequelae of encephalitis lethargica, inter alia neurofibrillary tangles composed of both $3 \mathrm{R}$ and $4 R$ tau isoforms were encountered [42,92]. Recently, Ramani et al. [81] found that SARS exposure on brain organoids associates with altered distribution of tau protein from axons to soma, tau hyperphosphorylation, neurotoxicity and death, driving neurodegeneration. Furthermore, Wang et al. [95] provide a causal link between the AD risk factor, ApoE4 and COVID-19. In their experiment, the ApoE4 neurons and astrocytes showed a higher susceptibility and a more severe response to SARS-CoV-2 infection in comparison to the neutral ApoE3 cells. Interestingly, the infection in neurons and astrocytes was inhibited by remdesivir [95].

The so-called "brain fog" reported by many patients during the active disease and post-COVID-19 is a term previously used for description of CNS side effects of chemotherapy. In this context, the cognitive and emotional changes in cancer patients are partially explained by many factors, including neuronal, axonal, glial lesions, alterations in brain perfusion and microenvironment, BBB dysfunction on the cellular interactions level. Moreover CVO region alteration mechanisms, oxidative stress, excitotoxicity, synaptic toxicity, and genetic polymorphic predisposal are debated. The important hypothesis comprises the inhibition of hippocampal and striatal neurogenesis and regeneration capacity $[7,15]$. All these ideas are plausible for the explanation of protracted neurological post-COVID-19 syndrome. Recently, long-term cerebral volume and blood flow variations have been reported (Qin, Wang and Zhu group) even in neurologically unchanged convalescents.

Neuropathological studies in post-COVID-19 cases do not exist yet, but together with neuroimaging studies should answer some questions. Neurocognitive and systemic complications associated with COVID-19 are extremely significant since these dis- eases affect global health nowadays, with limited treatment and prophylaxis options. Their influence on healthcare systems including social and economic burden can be even higher in the future $[23,47]$.

\section{Summary}

Neuropathological data in COVID-19 are relatively sparse and inconsistent as the studies concern the patients with different comorbidities and disease course, and are often performed on small groups. Variable definitions, selection bias, mainly retrospective analyses of hospitalized patients and different methodologies are implemented in the research of this new disease.

CNS pathology includes most frequently features of non-specific neuroinflammation with microglial activation and lymphoid infiltrations, ischemic/hypoxic encephalopathy, astrogliosis, acute cerebrovascular disease, secondary myelin injury, and microthrombi. Some brains of COVID-19 patients remained unaffected or show only non-specific changes. Many neuropathological findings are discrepant and not always comparable. Researchers should focus on designing longitudinal studies, with more frequent autopsies and creating dedicated brain banks. Cognitive impairment should be studied with the involvement of advanced neuroimaging techniques. Genetic predispositions or immunological factors corresponding to the disease profile as well as CSF or serum biomarkers of COVID-19, the impact of different virus variants and influence of therapy and vaccination need to be identified. The mechanisms causing neuroCOVID and cognitive impairment - whether they are infectious, toxic, vascular or metabolic - create other aspects under research. There are also many existential questions about post-COVID and delayed sequelae of the infection. The fight with this pandemic is a challenge for the global society, with neuropathologists and neuroscientists as important allies in struggle for understanding of the pathomechanisms of COVID-19 for better prevention and therapy of the patients.

\section{Disclosure}

The authors report no conflict of interest.

\section{References}

1. Agarwal S, Conway J, Nguyen V, Dogra S, Krieger P, Zagzag D, Lewis A, Melmed K, Galetta S, Jain R. Serial imaging of virus-as- 
sociated necrotizing disseminated acute leukoencephalopathy (VANDAL) in COVID-19. AJNR Am J Neuroradiol 2021; 4: 279-284.

2. Al-Dalahmah O, Thakur KT, Nordvig AS, Prust ML, Roth W, Lignelli A, Uhlemann AC, Miller EH, Kunnath-Velayudhan S, Del PortiIlo A, Liu Y, Hargus G, Teich AF, Hickman RA, Tanji K, Goldman JE, Faust PL, Canoll P. Neuronophagia and microglial nodules in a SARS-CoV-2 patient with cerebellar hemorrhage. Acta Neuropathol Commun 2020; 8: 147

3. Al-Sarraj S, Troakes C, Hanley B, Osborn M, Richardson MP, Hotopf M, Bullmore E, Everall IP. Invited review: the spectrum of neuropathology in COVID-19. Neuropathol Appl Neurobiol 2021; 47: 3-16.

4. Altable M, Moisés de la Serna J. Neuropathogenesis in COVID-19. J Neuropathol Exp Neurol 2020; 79: 1247-1249.

5. Athar H, Mukhtar N, Shah S, Mukhtar F. Depression and associated factors: a cross-sectional study using Beck depression inventory. J Ayub Med Coll Abbottabad 2017; 29: 667-670.

6. Bahi A, Mineur YS, Picciotto MR. Blockade of protein phosphatase $2 \mathrm{~B}$ activity in the amygdala increases anxiety- and depression-like behaviors in mice. Biol Psychiatry 2009; 66: 1139-1146.

7. Blommaert J, Schroyen G, Vandenbulcke M, Radwan A, Smeets A, eeters R, Sleurs C, Neven P, Wildiers H, Amant F, Sunaert S, Deprez $\mathrm{S}$. Age-dependent brain volume and neuropsychological changes after chemotherapy in breast cancer patients. Hum Brain Mapp 2019; 40: 4994-5010.

8. Brodin P. Immune determinants of COVID-19 disease presentation and severity. Nat Med 2021; 27: 28-33.

9. Bryce C, Grimes Z, Pujadas E, Ahuja S, Beasley MB, Albrecht R, Hernandez T, Stock A, Zhao Z, Rasheed M Al, Chen J, Li L, Wang D, Corben A, Haines K, Westra W, Umphlett M, Gordon RE, Reidy J, Petersen B, Salem F, Fiel M, El Jamal SM, Tsankova NM, Houldsworth J, Mussa Z, Liu W-C, Veremis B, Sordillo E, Gitman MR, Nowak M, Brody R, Harpaz N, Merad M, Gnjatic S, Donnelly R, Seigler P, Keys C, Cameron J, Moultrie I, Washington K-L, Treatman J, Sebra R, Jhang J, Firpo A, Lednicky J, Paniz-Mondolfi A, Cordon-Cardo C, Fowkes M. Pathophysiology of SARS-CoV-2: targeting of endothelial cells renders a complex disease with thrombotic microangiopathy and aberrant immune response. The Mount Sinai COVID-19 autopsy experience. medRxiv 2020.05.18.20099960.

10. Bulfamante G, Chiumello D, Canevini MP, Priori A, Mazzanti M CS. First ultrastructural autoptic findings of SARS-Cov-2 in olfactory pathways and brainstem. Minerva Anestesiol 2020; 86: 678-679.

11. Cantuti-Castelvetri L, Ojha R, Pedro LD, Djannatian M, Franz J, Kuivanen S, van der Meer F, Kallio K, Kaya T, Anastasina M, Smura T, Levanov L, Szirovicza L, Tobi A, Kallio-Kokko H, Österlund P, Joensuu M, Meunier FA, Butcher SJ, Winkler MS, Mollenhauer B, Helenius A, Gokce O, Teesalu T, Hepojoki J, Vapalahti O, Stadelmann C, Balistreri G, Simons M. Neuropilin-1 facilitates SARS CoV-2 cell entry and infectivity. Science 2020; 370: 856-860.

12. Cappellari M, Zini A, Sangalli D, Cavallini A, Reggiani M, Sepe FN, Rifino N, Giussani G, Guidetti D, Zedde M, Marcheselli S, Longoni M, Beretta S, Sidoti V, Papurello DM, Giossi A, Nencini P, Plocco M, Balestrino M, Rota E, Toni D. Thrombolysis and bridging therapy in patients with acute ischaemic stroke and Covid-19. Eur J Neurol 2020; 27: 2641-2645.
13. Carneiro T, Dashkoff J, Leung LY, Nobleza COS, Marulanda-Londono E, Hathidara M, Koch S, Sur N, Boske A, Voetsch B, Aboul Nour H, Miller DJ, Daneshmand A, Shulman J, Curiale G, Greer DM, Romero JR, Anand P, Cervantes-Arslanian AM. Intravenous tPA for Acute Ischemic Stroke in Patients with COVID-19. J Stroke Cerebrovasc Dis 2020; 29: 105201.

14. Cevik L, Alves M, Otero J. Neuropathologists play a key role in establishing the extent of COVID-19 in human patients. Free Neuropathol 2020; 1: 11.

15. Chiang ACA, Huo X, Kavelaars A, Heijnen CJ. Chemotherapy accelerates age-related development of tauopathy and results in loss of synaptic integrity and cognitive impairment. Brain Behav Immun 2019; 79: 319-325.

16. Choi R, Goldstein BJ. Olfactory epithelium: Cells, clinical disorders, and insights from an adult stem cell niche. Laryngoscope Investig Otolaryngol 2018; 3: 35-42.

17. De Cock KM, El-Sadr WM. A tale of two viruses: HIV, Ebola and health systems. AIDS 2015; 29: 989-991.

18. Coolen T, Lolli V, Sadeghi N, Rovai A, Trotta N, Taccone FS, Creteur J, Henrard S, Goffard JC, Dewitte O, Naeije G, Goldman S, De Tiège $X$. Early postmortem brain MRI findings in COVID-19 non-survivors. Neurology 2020; 95: e2016-2027.

19. Deffner F, Scharr M, Klingenstein S, Klingenstein M, Milazzo A, Scherer S, Wagner A, Hirt B, Mack AF, Neckel PH. Histological evidence for the enteric nervous system and the choroid plexus as alternative routes of neuroinvasion by SARS-CoV2. Front Neuroanat 2020; 14: 596439.

20. Deigendesch N, Sironi L, Kutza M, Wischnewski S, Fuchs V, Hench J, Frank A, Nienhold R, Mertz KD, Cathomas G, Matter MS, Siegemund M, Tolnay M, Schirmer L, Pröbstel AK, Tzankov A, Frank S. Correlates of critical illness-related encephalopathy predominate postmortem COVID-19 neuropathology. Acta Neuropathol 2020; 140: 583-586.

21. Delamarre L, Gollion C, Grouteau G, Rousset D, Jimena G, Roustan J, Gaussiat F, Aldige E, Gaffard C, Duplantier J, Martin C, Fourcade O, Bost C, Fortenfant F, Delobel P, Martin-Blondel G, Pariente J, Bonneville F, Geeraerts T, Grp NR. COVID-19-associated acute necrotising encephalopathy successfully treated with steroids and polyvalent immunoglobulin with unusual IgG targeting the cerebral fibre network. J Neurol Neurosurg Psychiatry 2020; 91: 1004-1006.

22. Dowlatshahi D, Stotts G, Bourgoin A, Gocan S, Dunn L, Powell J, Silver FL, Walker G, Yogendrakumar V, Fahed R, Blacquiere D, Shamy M. Decreased stroke presentation rates at a comprehensive stroke center during COVID-19. Can I Neurol Sci Le J Can des Sci Neurol 2021; 48: 118-121.

23. de Erausquin GA, Snyder H, Carrillo M, Hosseini AA, Brugha TS, Seshadri S, Consortium the CNSS-C-2. The chronic neuropsychiatric sequelae of COVID-19: The need for a prospective study of viral impact on brain functioning. Alzheimers Dement 2021. Online ahead of print.

24. Escalard S, Maïer B, Redjem H, Delvoye F, Hébert S, Smajda S, Ciccio G, Desilles JP, Mazighi M, Blanc R, Piotin M. Treatment of acute ischemic stroke due to large vessel occlusion with COVID-19: experience from Paris. Stroke 2020; 51: 2540-2543. 
25. Ferini-Strambi L, Salsone M. COVID-19 and neurological disorders: are neurodegenerative or neuroimmunological diseases more vulnerable? J Neurol 2021; 268: 409-419.

26. Fiani B, Covarrubias C, Desai A, Sekhon M, Jarrah R. A contemporary review of neurological sequelae of COVID-19. Front Neurol 2020; 11: 640.

27. Fontana IC, Bongarzone S, Gee A, Souza DO, Zimmer ER. PET imaging as a tool for assessing COVID-19 brain changes. Trends Neurosci 2020; 43: 935-938.

28. Fotuhi M, Mian A, Meysami S, Raji CA. Neurobiology of COVID-19. J Alzheimers Dis 2020; 76: 3-19.

29. Franca RA, Ugga L, Guadagno E, Russo D, Del Basso De Caro M. Neuroinvasive potential of SARS-CoV2 with neuroradiological and neuropathological findings: is the brain a target or a victim? APMIS 2021; 129: 37-54.

30. Franceschi AM, Ahmed O, Giliberto L, Castillo M. Hemorrhagic posterior reversible encephalopathy syndrome as a manifestation of COVID-19 infection. AJNR Am J Neuroradiol 2020; 41: 1173-1176.

31. Freij BJ, Gebara BM, Tariq R, Wang AM, Gibson J, El-Wiher N, Krasan G, Patek PM, Levasseur KA, Amin M, Fullmer JM. Fatal central nervous system co-infection with SARS-CoV-2 and tuberculosis in a healthy child. BMC Pediatr 2020; 20: 429.

32. Frontera JA, Sabadia S, Lalchan R, Fang T, Flusty B, Millar-Vernetti P, Snyder T, Berger S, Yang D, Granger A, Morgan N, Patel P, Gutman J, Melmed K, Agarwal S, Bokhari M, Andino A, Valdes E, Omari M, Kvernland A, Lillemoe K, Chou SH-Y, McNett M, Helbok R, Mainali S, Fink EL, Robertson C, Schober M, Suarez JI, Ziai W, Menon D, Friedman D, Friedman D, Holmes M, Huang J, Thawani S, Howard J, Abou-Fayssal N, Krieger P, Lewis A, Lord AS, Zhou T, Kahn DE, Czeisler BM, Torres J, Yaghi S, Ishida K, Scher E, de Havenon A, Placantonakis D, Liu M, Wisniewski T, Troxel AB, Balcer L, Galetta S. A prospective study of neurologic disorders in hospitalized COVID-19 patients in New York city. Neurology 2021; 96: e575-e586.

33. Galougahi MK, Ghorbani J, Bakhshayeshkaram M, Naeini AS, Haseli S. Olfactory bulb magnetic resonance imaging in SARS CoV-2-induced anosmia: the first report. Acad Radiol 2020; 27: 892-893.

34. Gandhi RT, Lynch JB, Del Rio C. Mild or moderate Covid-19. N Engl J Med 2020; 383: 1757-1766.

35. Garrigues E, Janvier P, Kherabi Y, Le Bot A, Hamon A, Gouze H, Doucet L, Berkani S, Oliosi E, Mallart E, Corre F, Zarrouk V, Moyer JD, Galy A, Honsel V, Fantin B, Nguyen Y. Post-discharge persistent symptoms and health-related quality of life after hospitalization for COVID-19. J Infect 2020; 81: e4-e6.

36. Goldstein DS. The possible association between COVID-19 and postural tachycardia syndrome. Heart Rhythm 2020; S15475271(20)31141-3.

37. Guo Y, Korteweg C, McNutt MA, Gu J. Pathogenetic mechanisms of severe acute respiratory syndrome. Virus Res 2008; 133: 4-12.

38. Hanley B, Naresh KN, Roufosse C, Nicholson AG, Weir J, Cooke GS, Thursz M, Manousou P, Corbett R, Goldin R, Al-Sarraj S, Abdolrasouli A, Swann OC, Baillon L, Penn R, Barclay WS, Viola P, Osborn M. Histopathological findings and viral tropism in UK patients with severe fatal COVID-19: a post-mortem study. Lancet Microbe 2020; 1: e245-e253.
39. Hawkins M, Sockalingam S, Bonato S, Rajaratnam T, Ravindran M, Gosse P, Sheehan KA. A rapid review of the pathoetiology, presentation, and management of delirium in adults with COVID-19. J Psychosom Res 2021; 141: 110350.

40. Heming M, LiX, Räuber S, Mausberg AK, Börsch AL, Hartlehnert M, Singhal A, Lu I-N, Fleischer M, Szepanowski F, Witzke O, Brenner T, Dittmer U, Yosef N, Kleinschnitz C, Wiendl H, Stettner M, Meyer Zu Hörste G. Neurological manifestations of COVID-19 feature $T$ cell exhaustion and dedifferentiated monocytes in cerebrospinal fluid. Immunity 2021; 54: 164-175.e6.

41. Hess DC, Eldahshan W, Rutkowski E. COVID-19-related stroke. Transl Stroke Res 2020; 11: 322-325.

42. Hoffman LA, Vilensky JA. Encephalitis lethargica: 100 years after the epidemic. Brain 2017; 140: 2246-2251.

43. Hosseini S, Wilk E, Michaelsen-Preusse K, Gerhauser I, Baumgärtner W, Geffers R, Schughart K, Korte M. Long-term neuroinflammation induced by influenza $A$ virus infection and the impact on hippocampal neuron morphology and function. J Neurosci 2018; 38: 3060-3080.

44. Iadecola C, Anrather J, Kamel H. Effects of COVID-19 on the nervous system. Cell 2020; 183: 16-27.e1.

45. Iba T, Levy JH, Levi M, Thachil J. Coagulopathy in COVID-19. J Thromb Haemost 2020; 18: 2103-2109.

46. Izycka-Swieszewska E, Zółtowska A, Rzepko R, Gross M, Borowska-Lehman J. Vasculopathy and amyloid beta reactivity in brains of patients with acquired immune deficiency (AIDS). Folia Neuropathol 2000; 38: 175-182.

47. Jansen van Vuren E, Steyn SF, Brink CB, Möller M, Viljoen FP, Harvey $\mathrm{BH}$. The neuropsychiatric manifestations of COVID-19: interactions with psychiatric illness and pharmacological treatment. Biomed Pharmacother 2021; 135: 111200.

48. Jaunmuktane Z, Mahadeva U, Green A, Sekhawat V, Barrett NA, Childs L, Shankar-Hari M, Thom M, Jäger HR, Brandner S. Microvascular injury and hypoxic damage: emerging neuropathological signatures in COVID-19. Acta Neuropathol 2020; 140: $397-$ 400.

49. Jensen MP, Le Quesne J, Officer-Jones L, Teodòsio A, Thaventhiran J, Ficken C, Goddard M, Smith C, Menon D, Allinson KSJ. Neuropathological findings in two patients with fatal COVID-19. Neuropathol Appl Neurobiol 2021; 47: 17-25.

50. Josephson SA, Kamel H. Neurology and COVID-19. JAMA 2020; 324: 1139-1140.

51. Kandemirli SG, Altundag A, Yildirim D, Tekcan Sanli DE, Saatci O. Olfactory bulb MRI and paranasal sinus CT findings in persistent COVID-19 anosmia. Acad Radiol 2021; 28: 28-35.

52. Kantonen J, Mahzabin S, Mäyränpää MI, Tynninen O, Paetau A, Andersson N, Sajantila A, Vapalahti O, Carpén O, Kekäläinen E, Kantele A, Myllykangas L. Neuropathologic features of four autopsied COVID-19 patients. Brain Pathol 2020; 30: 1012-1016.

53. Katz M. A short history of the long and productive search for the cause of subacute sclerosing panencephalitis. Folia Neuropathol 2009; 47: 145-148.

54. Keyhanian K, Umeton RP, Mohit B, Davoudi V, Hajighasemi F, Ghasemi M. SARS-CoV-2 and nervous system: From pathogenesis to clinical manifestation. J Neuroimmunol 2020; 350: 577436. 
55. Klok FA, Kruip MJHA, van der Meer NJM, Arbous MS, Gommers DAMPJ, Kant KM, Kaptein FHJ, van Paassen J, Stals MAM, Huisman M V, Endeman $H$. Incidence of thrombotic complications in critically ill ICU patients with COVID-19. Thromb Res 2020; 191: 145-147.

56. Kreye J, Reincke SM, Prüss H. Do cross-reactive antibodies cause neuropathology in COVID-19? Nat Rev Immunol 2020; 20: 645 646.

57. Lechien JR, Chiesa-Estomba CM, Varia LA, De Riu G, Cammaroto G, Chekkoury-Idrissi Y, Circiu M, Distinguin L, Journe F, de Terwangne C, Machayekhi S, Barillari MR, Calvo-Henriquez C, Hans S, Saussez S. Epidemiological, otolaryngological, olfactory and gustatory outcomes according to the severity of COVID-19: a study of 2579 patients. Eur Arch Otorhinolaryngol 2021; 1-9.

58. Lee DY, Lee WH, Wee JH, Kim JW. Prognosis of postviral olfactory loss: follow-up study for longer than one year. Am J Rhinol Allergy 2014; 28: 419-422.

59. Liberski PP. Historical overview of prion diseases: a view from afar. Folia Neuropathol 2012; 50: 1-12.

60. Liu JM, Tan BH, Wu S, Gui Y, Suo JL, Li YC. Evidence of central nervous system infection and neuroinvasive routes, as well as neurological involvement, in the lethality of SARS-CoV-2 infection. J Med Virol 2021; 93: 1304-1313.

61. Lou JJ, Movassaghi M, Gordy D, Olson MG, Zhang T, Khurana MS, Chen Z, Perez-Rosendahl M, Thammachantha S, Singer EJ, Magaki SD, Vinters H V, Yong WH. Neuropathology of COVID-19 (neuro-COVID): clinicopathological update. F Free Neuropathol 2021; $2: 2$.

62. Ludlow M, Kortekaas J, Herden C, Hoffmann B, Tappe D, Trebst C, Griffin DE, BrindleHE, Solomon T, BrownAS, van RielD, Wolthers KC, Pajkrt D, Wohlsein P, Martina BEE, Baumgärtner W, Verjans GM, Osterhaus ADME. Neurotropic virus infections as the cause of immediate and delayed neuropathology. Acta Neuropathol 2016; 131: 159-184.

63. MacLean MA, Kamintsky L, Leck ED, Friedman A. The potential role of microvascular pathology in the neurological manifestations of coronavirus infection. Fluids Barriers CNS 2020; 17: 55.

64. Mahammedi A, Saba L, Vagal A, Leali M, Rossi A, Gaskill M, Sengupta S, Zhang B, Carriero A, Bachir S, Crivelli P, Paschè A, Premi E, Padovani A, Gasparotti R. Imaging of neurologic dis ease in hospitalized patients with COVID-19: an Italian multicenter retrospective observational study. Radiology 2020; 297: E270-E273

65. Majidi S, Fifi JT, Ladner TR, Lara-Reyna J, Yaeger KA, Yim B, Dangayach N, Oxley TJ, Shigematsu T, Kummer BR, Stein LK, Weinberger J, Fara MG, De Leacy R, Dhamoon MS, Tuhrim S, Mocco J. Emergent large vessel occlusion stroke during New York city's COVID-19 outbreak: clinical characteristics and paraclinical findings. Stroke 2020; 51: 2656-2663.

66. Markus HS, Brainin M. COVID-19 and stroke - a global World Stroke Organization perspective. Int J Stroke 2020; 15: 361-364.

67. Matschke J, Lütgehetmann M, Hagel C, Sperhake JP, Schröder AS, Edler C, Mushumba H, Fitzek A, Allweiss L, Dandri M, Dottermusch M, Heinemann A, Pfefferle S, Schwabenland M, Sumner Magruder D, Bonn S, Prinz M, Gerloff C, Püschel K, Krasemann S, Aepfelbacher M, Glatzel M. Neuropathology of patients with
COVID-19 in Germany: a post-mortem case series. Lancet Neurol 2020; 19: 919-929.

68. Meinhardt J, Radke J, Dittmayer C, Franz J, Thomas C, Mothes R, Laue M, Schneider J, Brünink S, Greuel S, Lehmann M, Hassan O, Aschman T, Schumann E, Chua RL, Conrad C, Eils R, Stenzel W, Windgassen M, Rößler L, Goebel H-H, Gelderblom HR, Martin H, Nitsche A, Schulz-Schaeffer WJ, HakroushS, Winkler MS, Tampe B, Scheibe F, Körtvélyessy P, Reinhold D, Siegmund B, Kühl AA, Elezkurtaj S, Horst D, Oesterhelweg L, Tsokos M, Ingold-Heppner B, Stadelmann C, Drosten C, Corman VM, Radbruch H, Heppner FL. Olfactory transmucosal SARS-CoV-2 invasion as a port of central nervous system entry in individuals with COVID-19. Nat Neurosci 2021; 24: 168-175.

69. De Melo GD, Lazarini F, Levallois S, Hautefort C, Michel V, Larrous F, Verillaud B, Aparicio C, Wagner S, Gheusi G, Kergoat L, Kornobis E, Cokelaer T, Hervochon R, Madec Y, Roze E, Salmon D, Bourhy H, Lecuit M, Lledo P-M. COVID-19-associated olfactory dysfunction reveals SARS-CoV-2 neuroinvasion and persistence in the olfactory system. bioRxiv 2020.11.18.388819.

70. Merkler AE, Parikh NS, Mir S, Gupta A, Kamel H, Lin E, Lantos J, Schenck EJ, Goyal P, Bruce SS, Kahan J, Lansdale KN, LeMoss NM, Murthy SB, Stieg PE, Fink ME, Iadecola C, Segal AZ, Cusick M, Campion TRJ, Diaz I, Zhang C, Navi BB. Risk of ischemic stroke in patients with coronavirus disease 2019 (COVID-19) vs patients with influenza. JAMA Neurol 2020; 77: 1-7.

71. Mukerji SS, Solomon $\mathrm{IH}$. What can we learn from brain autopsies in COVID-19? Neurosci Lett 2021; 742: 135528.

72. Novi G, Rossi T, Pedemonte E, Saitta L, Rolla C, Roccatagliata L, Inglese M, Farinini D. Acute disseminated encephalomyelitis after SARS-CoV-2 infection. Neurol Neuroimmunol Neuroinflamm 2020; 7: e797.

73. Oxley TJ, Mocco J, Majidi S, Kellner CP, Shoirah H, Singh IP, De Leacy RA, Shigematsu T, Ladner TR, Yaeger KA, Skliut M, Weinberger J, Dangayach NS, Bederson JB, Tuhrim S, Fifi JT. Large-vessel stroke as a presenting feature of Covid-19 in the young. N Engl J Med 2020; 382: e60.

74. Paniz-Mondolfi A, Bryce C, Grimes Z, Gordon RE, Reidy J, Lednicky J, Sordillo EM, Fowkes M. Central nervous system involvement by severe acute respiratory syndrome coronavirus-2 (SARS-CoV-2). J Med Virol 2020; 92: 699-702.

75. Paterson RW, Brown RL, Benjamin L, Nortley R, Wiethoff S, Bharucha T, Jayaseelan DL, Kumar G, Raftopoulos RE, Zambreanu L, Vivekanandam V, Khoo A, Geraldes R, Chinthapalli K, Boyd E, Tuzlali H, Price G, Christofi G, Morrow J, McNamara P, McLoughlin B, Lim ST, Mehta PR, Levee V, Keddie S, Yong W, Trip SA, Foulkes AJM, Hotton G, Miller TD, Everitt AD, Carswell C, Davies NWS, Yoong M, Attwell D, Sreedharan J, Silber E, Schott JM, Chandratheva A, Perry RJ, Simister R, Checkley A, Longley N, Farmer SF, Carletti F, Houlihan C, Thom M, Lunn MP, Spillane J, Howard R, Vincent A, Werring DJ, Hoskote C, Jäger HR, Manji H, Zandi MS. The emerging spectrum of COVID-19 neurology: clinical, radiological and laboratory findings. Brain 2020; 143: 3104-3120.

76. Peng X, Ouyang J, Isnard S, Lin J, Fombuena B, Zhu B, Routy J-P. Sharing CD4+ T cell loss: when COVID-19 and HIV collide on immune system. Front Immunol 2020; 11: 596631. 
77. Perry VH, Holmes C. Microglial priming in neurodegenerative disease. Nat Rev Neurol 2014; 10: 217-224.

78. Politi LS, Salsano E, Grimaldi M. Magnetic resonance imaging alteration of the brain in a patient with coronavirus disease 2019 (COVID-19) and anosmia. JAMA Neurol 2020; 77: 10281029.

79. Poyiadji N, Shahin G, Noujaim D, Stone M, Patel S, Griffith B. COVID-19-associated acute hemorrhagic necrotizing encephalopathy: imaging features. Radiology 2020; 296: E119-E120.

80. Puelles VG, Lütgehetmann M, Lindenmeyer MT, Sperhake JP, Wong MN, Allweiss L, Chilla S, Heinemann A, Wanner N, Liu S, Braun F, Lu S, Pfefferle S, Schröder AS, Edler C, Gross O, Glatzel M, Wichmann D, Wiech T, Kluge S, Pueschel K, Aepfelbacher M, Huber TB. Multiorgan and renal tropism of SARS-CoV-2. N Engl J Med 2020; 383: 590-592.

81. Ramani A, Müller L, Ostermann PN, Gabriel E, Abida-Islam P, Müller-Schiffmann A, Mariappan A, Goureau O, Gruell H, Walker A, AndréeM,HaukaS, HouwaartT, DiltheyA, WohlgemuthK, OmranH, Klein F, Wieczorek D, Adams O, Timm J, Korth C, Schaal H, Gopalakrishnan J. SARS-CoV-2 targets neurons of 3D human brain organoids. EMBO J 2020; 39: e106230.

82. Reichard RR, Kashani KB, Boire NA, Constantopoulos E, Guo Y, Lucchinetti CF. Neuropathology of COVID-19: a spectrum of vascular and acute disseminated encephalomyelitis (ADEM)-like pathology. Acta Neuropathol 2020; 140: 1-6.

83. Remmelink M, De Mendonça R, D’Haene N, De Clercq S, Verocq C, Lebrun L, Lavis P, Racu ML, Trépant AL, Maris C, Rorive S, Goffard JC, De Witte O, Peluso L, Vincent JL, Decaestecker C, Taccone FS, Salmon I. Unspecific post-mortem findings despite multiorgan viral spread in COVID-19 patients. Crit Care 2020; 24: 495

84. Remsik J, Wilcox JA, Babady NE, McMillen TA, Vachha BA, Halpern NA, Dhawan V, Rosenblum M, lacobuzio-Donahue CA, Avila EK, Santomasso B, Boire A. Inflammatory leptomeningeal cytokines mediate COVID-19 neurologic symptoms in cancer patients. Cancer Cell 2021; 39: 276-283.e3.

85. Román GC, Spencer PS, Reis J, Buguet A, Faris MEA, Katrak SM, Láinez M, Medina MT, Meshram C, Mizusawa H, Öztürk S, Wasay $M$. The neurology of COVID-19 revisited: a proposal from the Environmental Neurology Specialty Group of the World Federation of Neurology to implement international neurological registries. J Neurol Sci 2020; 414: 116884.

86. Schaller T, Hirschbühl K, Burkhardt K, Braun G, Trepel M, Märkl B, Claus R. Postmortem examination of patients with COVID-19. JAMA 2020; 323: 2518-2520.

87. Solomon IH, Normandin E, Bhattacharyya S, Mukerji SS, Keller K, Ali AS, Adams G, Hornick JL, Padera RF, Sabeti P. Neuropathological features of Covid-19. N Engl I Med 2020; 383: 989-992.

88. Solomon T. Neurological infection with SARS-CoV-2 - the story so far. Nat Rev Neurol 2021; 17: 65-66.

89. Song E, Zhang C, Israelow B, Lu-Culligan A, Prado AV, Skriabine S, Lu P, Weizman O-E, Liu F, Dai Y, Szigeti-Buck K, Yasumoto Y, Wang G, Castaldi C, Heltke J, Ng E, Wheeler J, Alfajaro MM, Levavasseur E, Fontes B, Ravindra NG, Van Dijk D, Mane S, Gunel M, Ring A, Kazmi SAJ, Zhang K, Wilen CB, Horvath TL, Plu I, Haik S, Thomas JL, Louvi A, Farhadian SF, Huttner A, Seilhean D, Renier N, Bilguvar K, Iwasaki A. Neuroinvasion of SARS-CoV-2 in human and mouse brain. J Exp Med 2021; 218: e20202135.
90. Spudich S, Robertson KR, Bosch RJ, Gandhi RT, Cyktor JC, Mar H, Macatangay BJ, Lalama CM, Rinaldo C, Collier AC, Godfrey C, Eron JJ, McMahon D, Jacobs JL, Koontz D, Hogg E, Vecchio A, Mellors JW. Persistent HIV-infected cells in cerebrospinal fluid are associated with poorer neurocognitive performance. J Clin Invest 2019; 129: 3339-3346.

91. Sulzer D, Antonini A, Leta V, Nordvig A, Smeyne RJ, Goldman JE, Al-Dalahmah O, Zecca L, Sette A, Bubacco L, Meucci O, Moro E, Harms AS, Xu Y, Fahn S, Ray Chaudhuri K. COVID-19 and possible links with Parkinson's disease and parkinsonism: from bench to bedside. NPJ Parkinsons Dis 2020; 6: 18.

92. Taubenberger JK, Morens DM. The 1918 Influenza pandemic and its legacy. Cold Spring Harb Perspect Med 2020; 10: a038695.

93. Varga Z, Flammer AJ, Steiger P, Haberecker M, Andermatt R, Zinkernagel AS, Mehra MR, Schuepbach RA, Ruschitzka F, Moch H. Endothelial cell infection and endotheliitis in COVID-19. Lancet 2020; 395: 1417-1418.

94. De Virgiliis F, Di Giovanni S. Lung innervation in the eye of a cytokine storm: neuroimmune interactions and COVID-19. Nat Rev Neurol 2020; 16: 645-652.

95. Wang C, Zhang M, Garcia GJ, Tian E, Cui Q, Chen X, Sun G, Wang J, Arumugaswami V, Shi Y. ApoE-isoform-dependent SARS-CoV-2 neurotropism and cellular response. Cell Stem Cell 2021; 28: 331-342.e5.

96. Wang X, Xu W, Hu G, Xia S, Sun Z, Liu Z, Xie Y, Zhang R, Jiang S, LU L. RETRACTED ARTICLE: SARS-CoV-2 infects T lymphocytes through its spike protein-mediated membrane fusion. Cell Mol Immunol 2020; 1-3.

97. von Weyhern CH, Kaufmann I, Neff F, Kremer M. Early evidence of pronounced brain involvement in fatal COVID-19 outcomes. Lancet 2020; 395: e109.

98. Wierzba-Bobrowicz T, Lewandowska E, Felczak P, Stępień T, Acewicz A, Tarka S, Błażejewska-Hyżorek B, Bednarska A, Matyja E, Grajkowska W. Morphological and ultrastructural changes in Herpes simplex encephalomyelitis: an attempt to determinate the etiological factor. Folia Neuropathol 2020; 58: 143-150.

99. Yachou Y, El Idrissi A, Belapasov V, Ait Benali S. Neuroinvasion, neurotropic, and neuroinflammatory events of SARS-CoV-2: understanding the neurological manifestations in COVID-19 patients. Neurol Sci 2020; 41: 2657-2669.

100. Yavarpour-Bali H, Ghasemi-Kasman M. Update on neurological manifestations of COVID-19. Life Sci 2020; 257: 118063.

101. Younger DS. Postmortem neuropathology in COVID-19. Brain Pathol 2021; 31: 385-386.

102. Zhang Y, Xiao M, Zhang S, Xia P, Cao W, Jiang W, Chen H, Ding X, Zhao H, Zhang H, Wang C, Zhao J, Sun X, Tian R, Wu W, Wu D, Ma J, Chen Y, Zhang D, Xie J, Yan X, Zhou X, Liu Z, Wang J, Du B, Qin Y, Gao P, Qin X, Xu Y, Zhang W, Li T, Zhang F, Zhao Y, Li Y, Zhang S. Coagulopathy and antiphospholipid antibodies in patients with Covid-19. N Engl J Med 2020; 382: e38.

103. Zhao H, Shen D, Zhou H, Liu J, Chen S. Guillain-Barré syndrome associated with SARS-CoV-2 infection: causality or coincidence? Lancet Neurol 2020; 19: 383-384. 